This item was submitted to Loughborough's Research Repository by the author.

Items in Figshare are protected by copyright, with all rights reserved, unless otherwise indicated.

\title{
Persons shaping architecture: interview with Vito Acconci
}

PLEASE CITE THE PUBLISHED VERSION

http://dx.doi.org/10.1386/aps.1.2.189_7

\section{PUBLISHER}

(c) Intellect Ltd / @ the authors

VERSION

AM (Accepted Manuscript)

LICENCE

CC BY-NC-ND 4.0

\section{REPOSITORY RECORD}

Beech, Dave, Andy Hewitt, and Mel Jordan. 2019. "Persons Shaping Architecture: Interview with Vito Acconci". figshare. https://hdl.handle.net/2134/12852. 
This item was submitted to Loughborough's Institutional Repository (https://dspace.lboro.ac.uk/) by the author and is made available under the following Creative Commons Licence conditions.

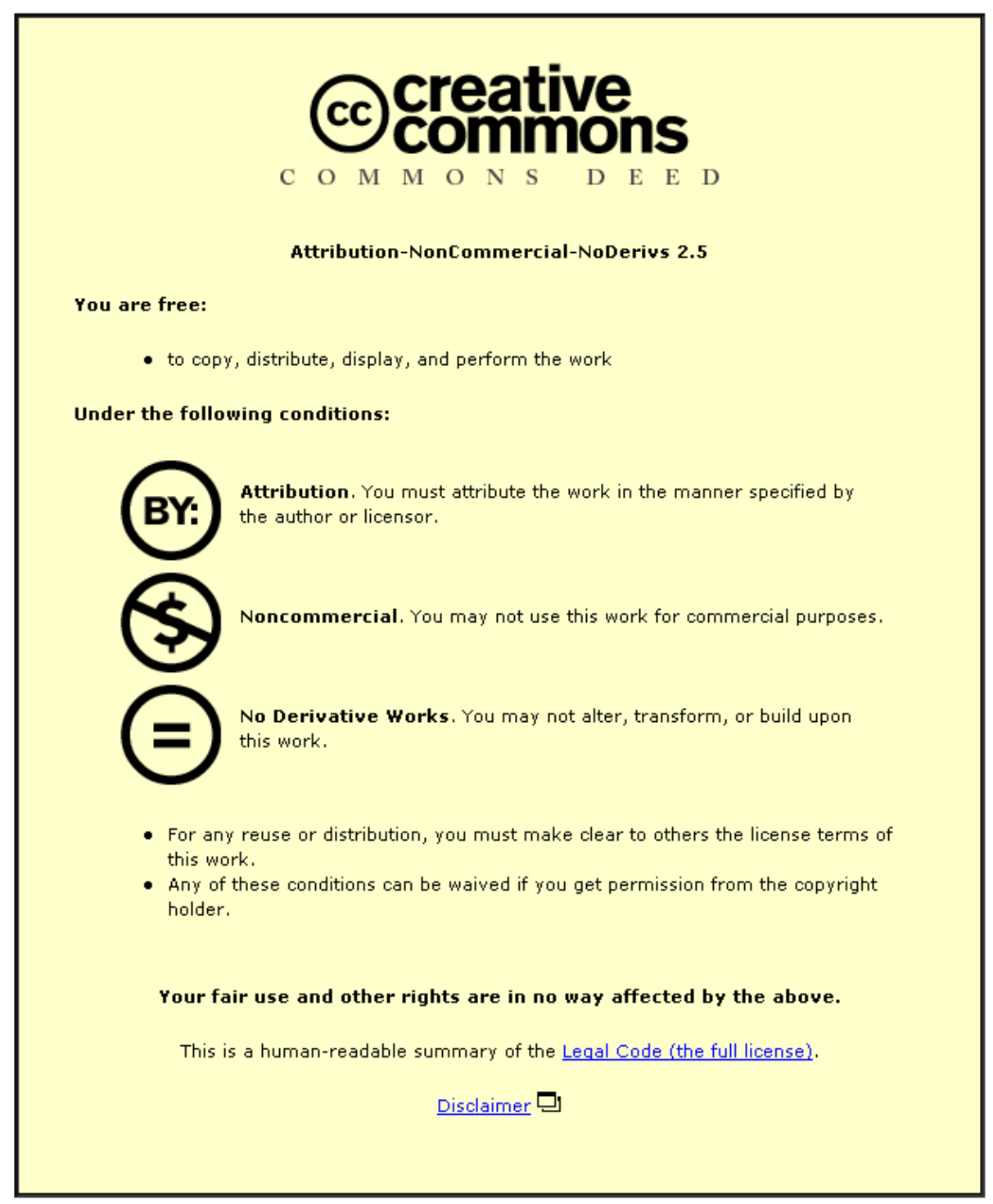

For the full text of this licence, please go to: http://creativecommons.org/licenses/by-nc-nd/2.5/ 
6232 words

Vito Acconci interviewed by Freee at Studio Acconci, New York, 26 ${ }^{\text {th }}$ February 2012.

Freee: You have shown a remarkable commitment to the individual as opposed to the social body in your work, as a poet, performance artist and for the past thirty years as an architect. Can you explain this, and also perhaps say something about whether architecture, which typically addresses itself to large multiples of people, makes it more difficult for you to address the individual in your work?

VA: I don't know if that was so much an interest in people as an interest in poetry, since the way I saw poetry, was making some kind of matter on a page. I wanted the words to be almost material. I don't think the notion of people for me, started until later. It might be present more than I think it is in the writing. But once I started doing live stuff, when I was writing a poem the way I thought about it was, "how do I move? How do I move from the left margin of the page to the right margin? How do I move from one page to the next page?” After a while I started thinking that if I was so interested in movement, why am I limiting it to this piece of paper? There's a floor out there, there's a ground, there's a world. So, by the end of the sixties, I was doing stuff in space. I've always thought the most convenient way of trying to get a feel of the time you're in is to pay attention to the music of that time. And at the end of the sixties it seemed like the typical music, the dominant music was longer - you know, a seven or eight minute song rather than two or three minutes. Usually a single voice, usually a male voice, it was a very male oriented time.

So that was probably the major reason why I thought I have to use myself in art pieces. But after a while I thought I'm doing something too enclosed in myself. I thought I can bring in another person. So I and he or she started doing something together but that becomes theatre. You know that's like treating other people as a kind of audience and I wasn't interested in that. I think I stole a lot of things from theatre but I didn't want this notion of, say the stage, this is where the spotlights are, and the audience is in front of the action. But if I and me seem too enclosed, if I and he or she seemed like theatre, I thought I'd have to start thinking of person-to-person relations. So I tried to do a number of pieces where I am some kind of you, usually in a situation were there were some kind of people in a gallery. But I didn't think there was a way to make contact with a whole group of people; either I'd feel small in relation to them or I'd try to be a kind of star figure, which I never wanted to be.

The notion of individual people became important so that gradually when I started to do installations I always wanted things to be used; there would be places for people. Although one of the reasons I thought I shouldn't be doing things in an art context anymore is all these 'do not touch' signs in museums. You know, it looks like it belongs to peoples but you know a chair in a museum is not really a chair. Laughs. So I thought things have to be in a public space.

Page 1 of 11 
Although, I always thought I don't like the word 'people' especially in the United States where there are expressions like 'we, the people'. How do I know if I have any connection to them? How do they know they have any kind of connection to me? The notion of 'persons' seems better to me. 'Persons' could be a large aggregate of individuals. But can you really get to those individuals? That's why most of the time, what I hate about architecture, is that when you design a space you are inherently designing people's behaviour in that space. So that when you do architecture you're in effect creating a sort of prison. Whether you want to or not. And I think the problem is that a lot of architects want to! Laughs Sure they might not be thinking that is what they are doing. A lot of architects are changing their design emphasis because of buzz words like sustainability etcetera; they are starting to act as if they are thinking about how individuals are in a place but I'm not sure if that's really true.

The interesting thing about architecture is that it is probably about time more than it is about space, because architecture can't really be viewed as a static image. You don't have the space in front of you, you're in the middle of the space and you're moving through it. So it's kind of instance, by instance by instance. The kind of ideal architecture we want to make is the kind of architecture in which the person can to shape the architecture as oppossed to being shaped by the architecture. I'm not sure if this can happen and I don't mean people are encouraged to form a group and 'do something to' the architecture. But can 'persons' have individual moments in architechture, for example can a person can go into a room and there's nothing there - maybe the point should be that there is nothing there until persons get there. A person feels tired, the person leans against the wall, the wall starts to recede and you have a seat for a while. You're not tired and you get up, the wall goes back. Another person comes in, has his or her own desire. I don't know how to do that kind of work but I think enough people are not just bothered by, but kind of enraged by the fact that when you are in architecture it tells you what kind of movements to make.

Freee: In 'Learning From Las Vegas' we come across a distinction between the piazza and the strip in an account of architecture for the pedestrian in closed spaces and architecture for the automobile driver. Would I be wrong in thinking that your architecture belongs to neither - that, instead, it seeks to tear down the closed public space of the piazza as well as, perhaps more interestingly, the closed private space of the interior of the car through which our bodies might encounter architecture?

VA: I probably know Los Angeles more than I know Las Vegas and there is probably that piazza car distinction as nobody walks. I feel more comfortable in a bus as I never learnt to drive. I mean I've been for a drive in New York but in New York there's a subway and the subway is open all night. Most blocks you can find a subway station. I'm very much a city person. A lot of European streets are closed off to cars and it has started to happen in New York too. Malls really don't exist in New York. There are shopping neighbourhoods and that in effect is a mall. I love 
the idea of a car. I've never driven one and I'm sure it does lead to privacy. Rather than a shopping mall I love the idea of a city street where you have to wait for the light or if you're talking to somebody you better look around. I like the notion of attention; I think you pay more attention to a person if you know there is a car there too.

To mix is really important. New York is kind of strange. If you ask people for directions people are kind of great, they're so open. I don't think they necessarily want to be your friend, but that's okay because we're not friends yet. But they have this kind of public familiarity but if you try to get too familiar, if somebody starts talking to me on the street I wonder if I get nervous. I say talking to each other should be a mutual choice.

I mean the nice thing about a street is that you're walking, you're trying to get somewhere, usually trying to get somewhere in a hurry. But then when you stop at a light to wait the relatively short time till the light changes, suddenly you realise - wow I can maybe even talk to these people, there is also this possibility in a subway. But if I ever started a conversation on a subway I think somebody might slap my face. Laughter

But the notion of the possibility of encounter seems really great in New York. When there are kinds of disasters in New York there's an amazing kind of...it's not a togetherness where you know you're going to be together for the rest of your life but it's - of course I'll help - what do you need? People think New York is not like that but I think it is, probably more than smaller cities where people think if I get to know this person am I going to have to keep knowing them? Whereas in New York you'd say it will pass. It's almost like you're inside a movie and the movie will change next week and next week...I find that healthy. I like the idea that you can be in the middle of people but you don't have to be obligated to them and they're not obligated to you. So it's almost like alone and together at the same time.

Freee Charles Jencks argued for a postmodernist architecture of double-coding, an architecture of fiction, fragmentation, montage and eclecticism that is to be 'read' as much as experienced or used. First, do you see this as the architecture of a very diluted version of the body, primarily the eye? And if so, does this remind you of the kind of visual culture in art that drove you to work with the body and performance? Second, your architecture is not symbolic or textual in this sense, nor does it pastiche historical architecture or pop culture, but it shares postmodernism's commitment to disorientation, doesn't it?

VA: In the late 70s early 80s I craved those Charles Jencks buildings. I don't know if I would have thought of the possibility of doing architecture if it wasn't for them; post-modern architecture gave me a way to read architecture similar to the way a child sees a building. They see the upper windows as eyes, the door as a mouth, you see something in between. So I realised 
wow! I can understand this now. I thought gee I can do this! This was in the early 80s before I started the studio I felt I could do architectural things, I could do furniture. I need people to do them with because I never really felt I could do things with my hands. I mean I come from words. And this is maybe a side thought but I was working with people because they could do things, things that moved for example - person sits in a swing, swing goes down but will also come up. But after a while I realised how these people aren't just building for me, I'm getting ideas from these people; I wouldn't have ideas for certain projects unless I could take for granted that this guy's going to find a way to do it, you know use people as kind of trouble shooters. So by the end of the 80s I thought I have to work as part of a group of people because I'd been doing that almost without admitting it.

Later on what I started to hate about postmodernism was this importation of another time that people feel comfortable with, certain things like pitched roofs. I started to think this is all wrong. I love the mix of things but it was like saying well you know the $20^{\text {th }}$ Century has been a little jarring and the $21^{\text {st }}$ Century might be even more jarring so let's bring in late $19^{\text {th }}$ Century for example New York lamp posts even though the light systems and technologies are totally different. That kind of thing really bothered me it just seemed like nostalgia. Like the world is uncomfortable, let's find a way to feel safer. But maybe this is because I was born in New York. I thought cities are supposed to be about the possibility of the unsafe. Architecture for me is about the possibility of the thing you don't expect and the thing about postmodernism is that it started to make architecture seem so expected.

It was also about architecture as a façade; architecture that once you went inside it was probably the same old architecture. It stressed the idea of architecture as a visual thing and I actually think architecture is totally the opposite of this. The way I really learned architecture is before I knew I'd learned architecture. I learned it from a movie called 'L'Annee Last Year in Marienbad' (1961) by Alain Robbe-Grillet and the French film maker Alain Resnais. The first part of the movie is a camera going through corridors of a baroque hotel and turning and turning. It was the most influential movie I've ever come upon in my life. It kind of foresaw everything I did. The narrator was important and I did a lot of stuff with voice and the notion of the instant. I know this movie is in front of me, I know it's not 3D, it's going through a space, it's not just being in front of a space. I think I kept that as a goal. I always wanted to do my version? When you see something you like you can like it and love it, at the same time you can't help thinking can I steal from this and not let anybody catch me!

Freee: Claire Bishop argues that participation asks more of the public than interaction, engaging it as a subject, not an object. Do you attempt something like this in your architecture? Grant Kester argues that the best kind of participation puts conversation at the heart of the experience. Do you want your architecture to be filled with conversations, and if so, what do you do to facilitate this in the design? 
VA: I used the word interaction but I don't think I've ever used the word participation and I wonder why? I think I used the word interaction because the way I think of spaces we do are places for people and then people can interact. I'll have to reconsider this participation word. I don't know if I've ever used it with regard to what we want from a project. I have a nagging doubt about the word. My nagging doubt is it almost seems like there's a kind of situation set up that if you participate in it are you becoming led by something? I really don't want to lead people. I want people to have the possibility of doing something with their space, with other people in the space that maybe they couldn't have had before.

Freee: Jacques Ranciere, in 'The Emancipated Spectator', argues against thinking of the public as passive and ignorant in need of radical interventions to wake it up and activate it. Do you feel that your architecture is interventionist? Do you have an idea of the condition of the individual before and after the building, so to speak? Do you think of publics, audiences, spectators, viewers, addressees and so forth, or do you have a different model in mind when you work?

VA: I don't think of people as passive and ignorant. I think, I have to assume most people are kind of uninformed, most people probably don't want to be bothered. At the same time I don't know if I want a work to tell people what to do. But if our projects don't lead people to think for themselves then I think they are a total failure.

Despite the fact that most of our projects are unbuilt, I really do think projects need to be built because only when people are in these spaces can people think for themselves. There's nothing wrong with pictures of a project except that they're easier to see than when you walk through them. With a picture you see it all at once, it's much easier to get ideas from it. But they might not be necessarily your ideas, it's set up to be seen in only that way. When I try to think who are the architects through the years that made me become an architect, if you're going to pick a magic circle, you know, the top three it would be Boullee and Piranesi in the $18^{\text {th }}$ Century and Archigram in the 60's (Peter Cook, Ron Herron, Warren Chalk, Michael Webb, Dennis Compton, David Greene). Not one built project! Laughs.

It's so much easier to get ideas through pictures. If you go to an Archigram book you continue to get ideas here and there. If you go to a space it takes a longer time. I don't think every architect is thinking this way, but they're setting up the best way to 'see' their building, so then allowing you to see it as they see it. I'm not saying there's something wrong with Boullee, Piranesi or with Archigram, but you're not necessarily getting your own ideas. Only when a person can go through a space by himself or herself do you start to think for yourself, or you start to be confused. You know the whole so much quicker by going to a space. A person doesn't change his or her mind or start to think 'wow I never thought of this before!' I'd rather the person say that, than me, as a preacher saying here is a new thought. Laughs 
Freee: Bertholt Brecht, who Ranciere dismisses, talked about the importance of interruption but to free theatre from the history of theatre, from technical expertise, and its customary forms of entertainment. It is, in effect, a call for relentless critical reflexivity for all involved. When we think of your architecture, it is this critical version of the theatre that comes to mind more than anything else. Do you believe that this kind of constant self-examination is necessary to your architecture?

VA: Brecht was always really important. Brecht made me realise, probably more than most theatre and movies, the notion of an actor getting into the role is really about making a spectator think not just feel. The Brecht notion of acting is you say it as if you're almost reading it. You say it as if it's apart from you. It's one way to make the audience realise that no I'm not going to be taken in, I'm going to judge for myself.

If a spectator isn't taken in by an actor then at least, in some way the spectator is free to make some kinds of decisions of his or her own. That seems so important to me. I've noticed there are some French or German movies made in the 70s where people spoke so strangely. They would make a traditional play and it was spoken so fast you almost couldn't understand a word. And it was done on a rooftop in Paris and you could hear the noise of the cars below. It really made you stop and think. But I don't think it told you what to think. I don't think it did and recently I think some of Lars von Trier movies, the way he's uses actors, they're acting as if they're almost sleepwalking and you start to wonder because you can't possibly be taken in. I know he has this reputation that anytime an actress works with him she'll never work with him again. But the way he got Nicole Kidman was kind of astonishing. Where people are knocking on a door in the air. It was pretty striking. There were other earlier versions but I don't know if I would have realised it if I hadn’t read Brecht or if I didn't see a von Trier movie.

I'm really struck by Marlon Brando's performance in On the Waterfront because in a way that's almost the opposite of the Brecht kind of acting. Like every once in a while some weird thing is thrown in. I mean that incredible scene in the taxi-cab with he and his brother played by Rod Steiger, the scene was supposedly done by each one of them individually. I don't know if that's true or not. It wasn't done in a taxi-cab. I realised that the back window of the taxi-cab has Venetian blinds. Laughs.

Freee: Sergei Eisenstein asked, "why should the cinema follow the forms of theatre and painting rather than the methodology of language, which allows wholly new concepts of ideas to arise from the combination of two concrete denotations of two concrete objects?" As someone who started out as a poet, would you agree with Eisenstein and say that architecture can produce new ideas through montage in this way?

VA: Eisenstein used cuts - this object, this object, this object. So you have this and you cut to that. Cut is important. It was interesting, recently there was this Russian movie by a 
guy named Alexander Sokurov called 'Russian Ark', (2002). It's the kind of movie you can only make on video because it's approximately a two hour movie with no cuts. One continuous take. It's kind of astonishing and it's done in the Hermitage in Russia. When I saw it I met these two Russians and I was saying god this is an incredible movie and these two Russians said to me you were fooled. I said what do you mean? They said the whole reason that movie is a continuous take is that it's a denial of the Soviet Revolution. I loved that argument, I don't know if it's right I mean they never mentioned the revolution but it's there, it's there like outside the door. So I don't know if they're totally right but what I like is the idea that form is not just form. Form tells something. I understand why that in the same way Eisenstein says you shouldn't take the methods of theatre.

I wonder can you do it in architecture? I don't know if we've been able to do it because I don't think our projects are big enough. I wonder if you have it where you are in one space and then you go around the corner and now it's something else and then something else. That's almost like using the method of a movie for architecture. I wonder if you could in the future since now there is this possibility; can you mix the physical and the so called virtual in architecture? I always thought the virtual was not quite enough but I wonder if the joining of both, if that's a way you can be in one space and totally turn it to something else, then into something else. Right now the virtual is merely a projection but that's only the beginning of virtual. It's going to be wicked you know. Laughs.

Freee: Walter Benjamin, in 'The Author as Producer', calls for the disappearance of the distinction between the author and the public. You are not a formally trained architect, so do you regard yourself as a member of the public occupying the privileged place of the producer, here? And do you design your architecture with this kind of turning of tables in mind? Do you want the users of architecture to also redesign it?

VA: I mean I can handle the last part of the question. Definitely I want an architecture that people can change. It has to be something that impels or at least gives a clue to users that they can do it too, they can change this. We don't exactly know how to do it yet but I think it's so important, that's why I mentioned before that people using the architecture become prisoners and I would love architecture to give people the freedom to take something and do their own thing.

Its not a case of not doing anything, I don't think it can be that. I think we have to put something in place so it will always be that we're 'giving' at the start. I don't know how to give people, persons, users, the incentive to do something. Even then if we start it off maybe we may have designed the plot too much. Yeah, I have a real double bind about that; it's not that I want to put some materials in a space and shrug our shoulders and go off and leave them to it.

I want to go back to that word 'persons'. I think 'persons' if given the chance would want to do so many different kinds of things. I don't know if it's a matter of people coming together and deciding we want to do this. I'm talking architecture where maybe we set something in place and 
the person changes it, somebody changes it. How can you provide the freedom and power to do architecture? Can we do an architecture that asks to be overturned? Can we do architecture that impels a revolution? Can we do an architecture that says kick me, turn me upside down, throw me up in the air, see what you get. I don't know.

I love the idea that we do a space that people can go through in time. I don't know if I'd want to have words there but there should be no doubt for the user that this place is saying to me now it's your turn. It's your turn now, take-over. This is what we did, what can you do with it? I think that would be incredible if that could happen. We have to find a way to make it happen, it's not going to happen without us and some other people, thinking like that. Yeah.

Freee: Marshall McLuhan sees architecture as an extension of the body, and reads the difference, for instance, between circular and rectilinear structures as arising from the difference between different forms of social being. Do you think about your architecture in these social terms? What kind of society builds structures like yours? Or what kind of societies do your structures desire?

VA: I don't remember reading that in McLuhan, the circular and the rectilinear that's interesting. It starts with clothing. The way skin covers bones, clothing covers skin and bones. Then the next step away from clothing is something that you use with your hands. A tool, an appliance, a utensil. Then the next step out from the body is furniture and they are probably two kinds of furniture. There's 'platform' and 'container'. You know 'platform' might be this stool we are sitting on. Once a chair has a back and arms it starts to be more container like or for example I think of shelves as containers. And then maybe to the interior of a building, I don't know if I want to say it starts with the body but it does start from something that you would use on the individual body. Also I love the fact that clothing is at probably one and the same time the most private and the most public; it's private in the sense that, yeah it is hiding your private parts but it is public in the sense that it is attractive, of course it might not be conventionally attractive but it might attract somebody to look at you. But you know we would love to do something that starts as clothing, and then say now you can transform it into a kind of furniture, then now you can extend it into a kind of house but any moment it could return to clothing and when you want to move it, you can carry it on your back.

I think there are two kinds of building. There is circular and rectilinear and sure now is a time when it's easier to build things that don't have to be rectilinear. I don't particularly like the idea of 'corners', 'corners' seem to be an end point. I can't say that I like curves but what I like about what curves do is that they make you decide where the floor ends or they help you not even think about the concept of a floor, a wall or a ceiling anymore.

I think there are two kinds of building; the building that kind of embeds itself in itself and constantly circles around. There are two kinds of spirals; you can start a spiral from the outside 
and make a house that way but it you start the spiral in the middle, well the house can go on forever, it doesn't even always have to be a circle. It can go around and around.

If a spiral or a circle embeds the house in itself then what about the house that stretches? The house that stretches is like going away from home. You go over to the next neighbourhood, you know the house that leaps or maybe a third kind of house. Let's start with that kind of circle again but then let's take the surface and tear it. Let's tear it, let's make breaks in it.

Freee. Jonathan Raban, in 'Soft City', says that cities are more malleable than villages and small towns, and that 'the soft city of illusion, myth, aspiration, nightmare, is as real, maybe more real, than the hard city one can locate in maps". Your works has always been soft in this sense, using the body and the physical environment to explore desire, fear and the edges of identity. How does your architecture - items within the hard city - bring the soft city to the foreground?

VA: Oh I mean you're right to make that connection. We love the idea of a prefab building but more the idea of, can we have a building that will be one kind of thing in one place? Or ideally can we do a building that breeds? I don't know how to do this. Can we do a building that's always malleable? I mean the idea of a prefab building is kind of interesting. What it usually leads to is the same building here, the same building some other place. But can you do a prefab building that builds into some notion of wherever this place is, wherever this building is now and it starts to mix with its environment - so it's not you take this prefabricated thing and the same thing appears in the same way. I don't even know what this would achieve.

I want to go back to the question of the soft city, it's not that I don't want to think in terms of the whole city, I feel more comfortable in thinking about one building at a time. One neighbourhood at a time, thinking of the whole city seems...I don't know....would we want to design an entire city? I'm not sure. If we did we would do patches you know. Maybe, if ten, twelve different designers did it and argued all the time while they were doing it. You know the first time I went to Brazil I definitely wanted to see Brasilia and it was kind of astonishing but it was kind of horrendous too.

The idea of a city being monolithic, it's not a city anymore. Laughs It's supposed to be a jumble, it's supposed to be an aggregation. It's not that the city in itself has a system. New York tries with this grid but then it's nicely spoiled by a diagonal street like Broadway. The diagonal thickens the plot.

Freee: Jane Jacobs talks about how the traditional techniques by which the community looks after itself and the strangers that pass through it - reputation, gossip, approval, disapproval and sanctions - are largely ineffective in cities, but to respond to unease streets by building safe courtyards is to fail to see how cities might function better. Does your architecture deliberately open itself to public spaces in this way, rather than create little private havens? 
VA: I read Jane Jacobs when that book came out before I thought I had any kind of interest in architecture. She uses the West Village as an example for a lot of stuff. I think when she's saying small neighbourhoods she focuses on communities that know each other. So I didn't think she was saying it's ineffective in cities, I thought she was saying that it needs areas like the West Village instead of say Manhattan. It's too hard to deal with Manhattan.

These two American people Andrés Duany and Elizabeth Plater-Zyberk, they do a lot of stuff around Miami. They do these things called new towns. It's a slightly different version of postmodernism but it's like you build a community first before the people. That idea is such an amazing kind of throwback. I was about to say this strange notion that the shape of this assemblage of buildings are going to make kinds of people, but isn't that what we're doing too? Laughter. Maybe the aims were a little different, maybe we're saying that this kind of stuff would lead to freedom, would lead to maybe a new kind of architecture done by the people themselves. The new town movement is about making the city into one of these small towns. So you make neighbourhoods. But you know I think the aim there is that it's more a continuity of something rather than breakage. But the thing is whatever you're telling people you're still telling people what to do.

Hopefully if you think your ideas are good enough you'd want users but I don't think either you or us want users to be taught by something. But to be moved, but to be urged by something to some kind of change. I don't know if I want to define the change that's happening.

Freee: Michel de Certeau distinguished between 'place' and 'space'. For him, 'place' implies an 'indication of stability' while 'space', by contrast, 'occurs as the effect produced by the operations that orient it, situate it, temporalize it, and make it function in a polyvalent unity of conflictual programmes or contractual proximities'. Space is not established through the work of building, but the activities - what he calls the 'intersection of mobile elements' - that cut across, lurk around and temporarily customise the built environment. How does your architecture address these 'mobile elements'?

VA: I don't remember that distinction. I always use space as more abstract, or where place is seeing the same notion of space but seeing it in both very concrete and changeable. I even saw place as the opposite of stability...but that part doesn't matter. I mean the thing I like about cities are mobile elements, that space might be defined by moving people and moving vehicles. The idea that there are these crossing currents and they're changing and that there are people entering the city. One thing I love about New York is that I see people coming towards me and I've no idea what nationality they are. You'd probably see a lot of that same mix every day in a smaller city but in a larger city you almost can't recognise it. You see too many people to recognise. The great thing about a city is there are cross currents and by currents I mean they're not static. It's like a river and rivulet system, on some streets these are the rivers but then they go off to these 
other things. But they're composed of people that are always changing. Whereas I know in a river and rivulet you know it's never the same water twice but it looks the same. Laughs But when you see these currents of changing faces and changing walks it seems like, it's an activity place.

I'm not saying anything different to de Certeau. That's why I think the city of the future is going to be a moving city, moving places. It seems almost every place in the world people are so upset by immigrants. There's such indignation of people, I think it's a sure sign that soon there aren't going to be any immigrants. I don't mean that they would be kept out, I don't think you can stop immigrants and you shouldn't, so that eventually I think what will change is the boundaries of a city. I don't know if there'll be boundaries, I don't know if there'll be cities and people will be able to go anywhere at will. I think it might be a kind of new nomad and that might not be so bad because you know you're not kept out, you can go anywhere. I mean someone won't want you in, of course that's going to lead to protection of one's own space. Maybe that means that it will be more convenient to bring your building with you. 